혈전을 둥반한 경둥맥 둥맥류에 의하여 발생한 눈돌림신경마비 환자에서 성궁적인 스텐트 보조 코일 색전술 치료

권하님 이규봉 박윤직 김건우 이덕희 ${ }^{a}$ 임영민 김광국 이은재

울산대학교 의과대학 서울아산병원 신경과, 영상의학과 ${ }^{a}$

\title{
A Successful Stent-Assisted Coil Embolization in a Patient with Oculomotor Palsy Due to Partially Thrombosed-Aneurysm in Cavernous Internal Carotid Artery
}

Hanim Kwon, MD, Kyu Bong Lee, MD, Yun Jik Park, MD, Geonwoo Kim, MD, Deok Hee Lee, MDa, Young-Min Lim, MD, Kwang-Kuk Kim, MD, Eun-Jae Lee, MD

Departments of Neurology and Diagnostic Radiology ${ }^{\mathrm{a}}$, Asan Medical Center, University of Ulsan College of Medicine, Seoul, Korea

J Korean Neurol Assoc 37(4):426-428, 2019

Key Words: Intracranial aneurysm, Oculomotor nerve diseases, Endovascular procedures

뇌동맥류의 신경증상은 병변의 위치에 따라 다양하게 나타날 수 있으며 눈돌림신경마비에 의한 증상도 그중 하나이다. 저자들은 최근 내경동맥의 해면정맥굴 부분에 발생한 부분 혈전을 동반한 뇌동맥류로 인하여 눈돌림신경마비가 발생한 환자에서 스텐트 보 조 코일 색전술(stent-assisted coil embolization) 시행 후 눈돌림신 경마비가 완전히 회복된 것을 경험하였기에 보고하고자 한다.

\section{중 례}

67세 남자가 3일 전부터 발생한 좌안 통증과 양안 복시로 응급 실로 왔다. 통증은 욱신거리는 양상이었고 통증평가척도 8-10점 정도로 심하였다. 증상 발생 다음날부터 좌측 눈꺼풀이 처졌고, 셋 째 날부터 좌안의 움직임이 제한되었다.

Received May 27, 2019 Revised August 14, 2019

Accepted August 14, 2019

Address for correspondence: Eun-Jae Lee, MD

Department of Neurology, Asan Medical Center, University of Ulsan College of Medicine, 88 Olympic-ro 43-gil, Songpa-gu, Seoul 05505, Korea

Tel: +82-2-3010-3440 Fax: +82-2-3010-1111

E-mail: siverash@gmail.com
30년 전부터 고혈압약을 복용하고 있었고, immunoglobulin A 콩팥병증으로 27년 전 콩팥 이식을 받고 면역억제제를 복용 중이 었다(사이클로스포린 $50 \mathrm{mg}$ 하루 2회, 마이코페놀레이트 모페틸 $250 \mathrm{mg}$ 하루 1 회, 프레드니솔론 $5 \mathrm{mg}$ 하루 1회). 콩팥 이식 이후 투석은 하지 않았으나 사구체 여과율이 만성 콩팥병증 범위였다. 복시가 발생하기 전 발열, 기침, 가래와 같은 감염은 없었고 복통, 설사도 없었다.

내원 당시 활력징후는 정상이었다. 신경학적검사에서 좌측의 안 검하수, 외사시, 하사시가 관찰되었으며 좌측 동공이 산동되어 있 었고(좌안 $4 \mathrm{~mm}$, 우안 $3 \mathrm{~mm}$ ), 빛반사도 떨어져 있었다. 또한, 좌 안의 상전, 하전 그리고 내전의 제한이 확인되었지만 좌안을 하전 시켰을 때 내회선은 잘 관찰되었다. 우안은 정상이었다. 좌안 주변 으로 심한 통증을 호소하고 있었으나 얼굴 감각저하는 없었으며 양측 각막반사를 포함한 다른 뇌신경검사와 운동 및 감각기능검사 도 정상이었다. 실조증은 없었고 심부건반사도 정상이었다.

혈액검사에서 C-반응단백 $0.1 \mathrm{mg} / \mathrm{dL}$ 로 정상이었고, 적혈구침윤 속도 $21 \mathrm{~mm} / \mathrm{hr}$ 로 약한 염증 반응을 시사하였으며, 크레아티닌 $2.08 \mathrm{mg} / \mathrm{dL}$, 혈중요소질소 $23 \mathrm{mg} / \mathrm{dL}$, 사구체 여과율 $32 \mathrm{~mL} / \mathrm{min} /$ $1.73 \mathrm{~m}^{2}$ 로 콩팥 기능은 환자의 평소 상태와 비슷하였다. 뇌 자기공명 
영상에서 뇌실질은 정상이었으나 왼쪽 눈돌림신경이 바깥쪽으로 치우쳤으며, 두꺼워지고 조영증강되는 소견을 보였다. 뇌 자기공명 혈관조영검사에서 $1.3 \mathrm{~cm}$ 정도 크기의 뇌동맥류가 왼쪽 내경동맥의 해면정맥굴 부분에서 발견되었으며(Fig. A) 그 안쪽으로 일부 조영 제가 채워지지 않는 부분이 있어 동맥류 내부에 부분적으로 혈전이 있는 것으로 생각되었다. 뇌 자기공명영상에서 원인이 뚜렷하게 확인 되어 뇌척수액검사는 진행하지 않았다. 수술 전 사시 정도를 평가하 기 위하여 시행한 헤스(Hess)검사에서도 좌안의 외사시와 하사시가 보였다(Fig. B)

입원 4일째에 동맥류 병변에 대하여 스텐트 보조 코일 색전술을 시행하였다. 마이크로카데터를 모혈관(parent artery)으로 진입시 킨 후 뇌동맥류를 선택하여 코일로 틀을 만들었다. 이후 그 위에 스텐트를 거치시켜 마이크로카데터 코일이 스텐트와 뇌혈관 사이 에 갇히도록(jailing) 하면서 색전술을 하였고, 뇌동맥류에 코일을 채워 시술을 종료하였다(Fig. C). 시술 1일 전부터 아스피린 $300 \mathrm{mg}$, 클로피도그렐 $300 \mathrm{mg}$ 을 투약하였으며, 이 과정에서 클로피도그렐
저항성이 확인되어(P2Y12 resistance unit 214, 25\%), 아스피린 $200 \mathrm{mg}$, 클로피도그렐 $75 \mathrm{mg}$, 실로스타졸 서방정 $200 \mathrm{mg}$ 을 하루 1 회 복용하며 시술 후 5 일째 퇴원하였다.

퇴원 시 좌안의 내전이 일부 호전되었고, 시술 후 3 개월 시점에 는 증상이 모두 소실되었다(Fig. D). 시술 후 7개월 시점부터 아스 피린 $100 \mathrm{mg}$ 단일 투약으로 변경하였다. 추적관찰한 뇌 자기공명 혈관검사에서 뇌동맥류는 재발하지 않았으며, 스텐트를 삽입한 모 혈관의 혈류도 잘 유지되는 것을 확인할 수 있었다.

\section{고 찰}

환자는 좌측의 동공 확대와 눈돌림신경의 이상을 보였다. 눈돌 림신경 이상은 혈관성, 감염성, 염증성 혹은 허혈성으로 발생할 수 있으며 또한 종양이나 안근마비편두통 등 다양한 질환에 의하여 발생할 수 있다. 그러나 외안근 이상뿐 아니라 동공 확대도 동반하 는 경우에는 동맥류나 종양 등에 의한 압박성 눈돌림신경마비 가 능성이 높으며, 그 이유는 동공 기능을 담당하는 신경섬유가 눈돌
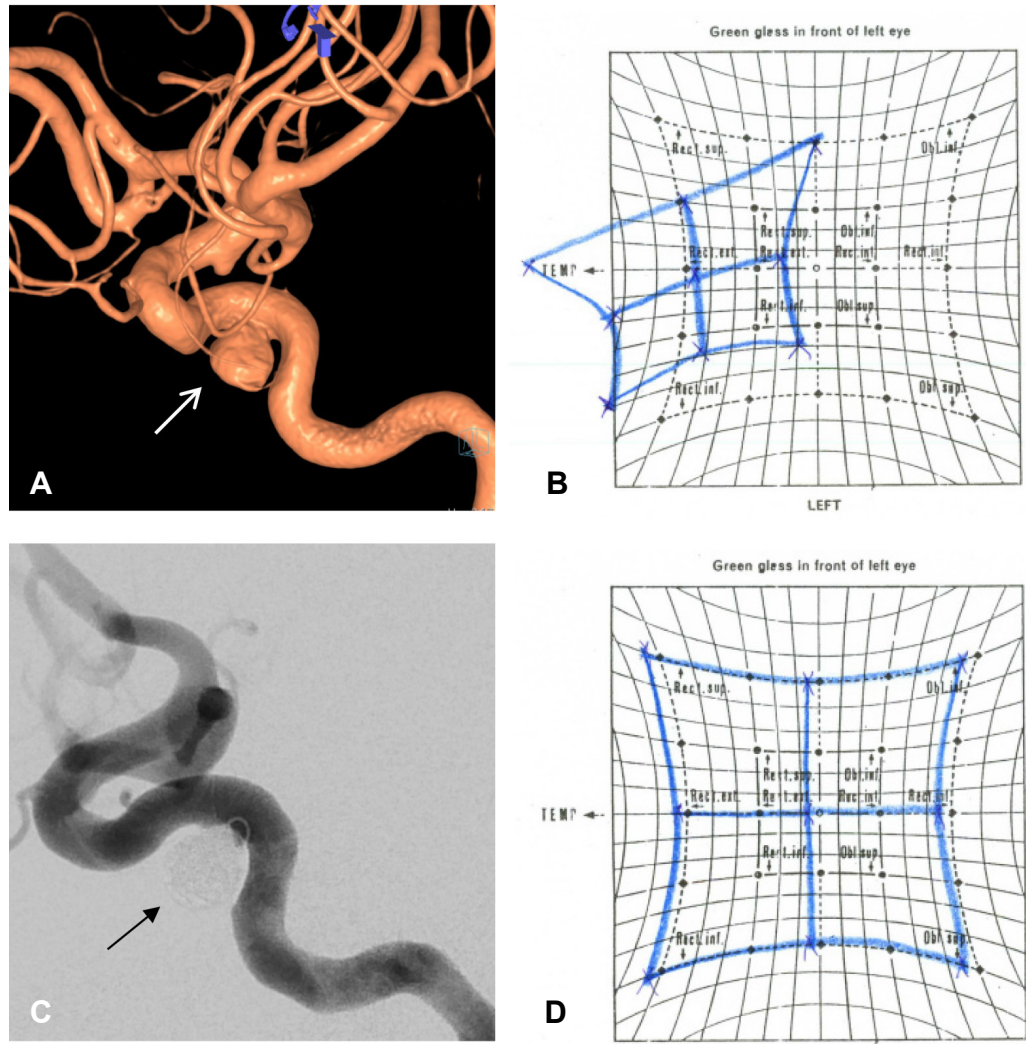
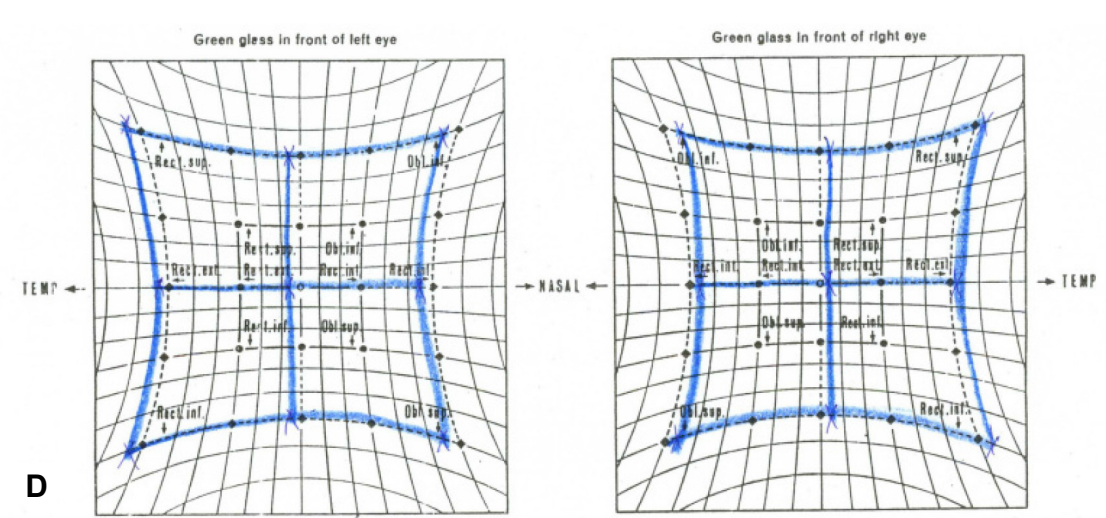

Figure. (A, B) Transfemoral cerebral angiography and Hess test before and (C, D) 3 months after the stent-assisted embolization. (A) A $1.3 \mathrm{~cm}$-sized partially thrombosed aneurysm (arrow) is shown in the left internal carotid artery. (B) Hess test demonstrates exotropia and hypotropia of the left eye. (C) Arrow indicates the successfully embolized aneurysm with coil. (D) Hess test performed at 3 months later reveals normalized diplopia. 
림신경의 가장 표면에 위치하고 있어 압박성 병변에 취약하기 때 문으로 알려져 있다.

본 증례의 경우 뇌 자기공명영상검사 및 혈관조영검사에서 왼쪽 내경동맥의 해면정맥굴 부분에 혈전을 동반한 뇌동맥류가 관찰되 었고, 그로 인하여 눈돌림신경이 압박을 받고 있었다. 동맥류의 크 기가 직경 $1.3 \mathrm{~cm}$ 정도로 컸고, 뇌신경장애가 동반되었기 때문에 빠른 치료가 필요하다고 판단되었다. ${ }^{2}$

치료 방법으로는 스텐트 보조 코일 색전술을 선택하였다. 코일 색전술의 단점은 뇌동맥류의 목이 넓은 경우에 뇌동맥류가 재개통 될 가능성이 높다는 점인데, 이 방법을 사용하면 재개통 확률을 낮 출 수 있다. 다만 스텐트 내 혈전증이 발생할 가능성 있기 때문에 시술 전후 필수적으로 항혈소판제를 사용해야 한다. 적어도 시술 후 3 개월까지는 항혈소판제 두 가지를 같이 사용해야 하고, 이후에 도 아스피린 단독 요법을 평생 유지하도록 권고하고 있다. ${ }^{3}$

모혈관 폐쇄술이 혈전이 동반된 뇌동맥류에서 일반적인 코일 색 전술보다 효과적이라는 연구 결과가 있다. ${ }^{4.5}$ 혈전이 동반된 뇌동맥 류는 대개 크기가 크기 때문에 코일 색전술을 시행할 경우 많은 환자(75\%)에서 동맥류가 재개통된다. 이에 비하여 모혈관 폐쇄술 을 시행한 경우 동맥류가 커지지 않을 뿐 아니라 대부분의 경우 줄어드는 경향을 보인다. 그 이유는 혈전을 동반한 뇌동맥류에서 크기가 커지는 기전 중 하나가 동맥류 벽이 찢어지기 때문인데, 모 혈관 폐쇄술을 사용하면 이를 막을 수 있기 때문이다. ${ }^{5}$ 그러나 본 환자에서는 동맥류가 내경동맥에서 기시하고 있었기 때문에 뇌경 색 위험이 있어 모혈관 폐쇄술을 시행하기 어려웠다.
본 증례는 왼쪽 내경동맥에서 기시한 혈전을 동반한 뇌동맥류로 인하여 왼쪽 눈돌림신경마비가 발생한 환자로, 스텐트 보조 코일 색전술 이후 신경학적 이상이 완전히 호전된 경우였다. 뇌동맥류 로 인한 압박성 신경병증이 심하고 동맥류의 목 부분이 넓은 경우, 수술적 접근이 어려운 경우라면 스텐트 보조 혈관색전술로 좋은 효과를 볼 수 있다는 것을 이 증례를 통하여 경험하였기에 보고하 는 바이다.

\section{REFERENCES}

1. Yanovitch T, Buckley E. Diagnosis and management of third nerve palsy. Curr Opin Ophthalmol 2007;18:373-378.

2. Thompson BG, Brown RD Jr, Amin-Hanjani S, Broderick JP, Cockroft $\mathrm{KM}$, Connolly ES Jr, et al. Guidelines for the management of patients with unruptured intracranial aneurysms: a guideline for healthcare professionals from the American Heart Association/American Stroke Association. Stroke 2015;46:2368-2400.

3. Biondi A, Janardhan V, Katz JM, Salvaggio K, Riina HA, Gobin YP. Neuroform stent-assisted coil embolization of wide-neck intracranial aneurysms: strategies in stent deployment and midterm follow-up. Neurosurgery 2007;61:460-468.

4. Becske T, Kallmes DF, Saatci I, McDougall CG, Szikora I, Lanzino G, et al. Pipeline for uncoilable or failed aneurysms: results from a multicenter clinical trial. Radiology 2013;267:858-868.

5. Ferns SP, van Rooij WJ, Sluzewski M, van den Berg R, Majoie CB. Partially thrombosed intracranial aneurysms presenting with mass effect: long-term clinical and imaging follow-up after endovascular treatment. AJNR Am J Neuroradiol 2010;31:1197-1205. 